T.V. Fesenko, I.V. Laguta, O.M. Stavynska, O.I. Oranska

\title{
SYNTHESIS OF CERIUM OXIDE NANOPARTICLES USING VITEX EXTRACT
}

\author{
Chuiko Institute of Surface Chemistry of National Academy of Sciences of Ukraine \\ 17 General Naumov Str., Kyiv,03164,Ukraine, E-mail: t.fesenko@gmail.com
}

\begin{abstract}
The aim of this work was to study composition and antioxidant/reducing properties of Vitex cannabifolia leaves extract and to characterize it as a possible active agent for green synthesis of cerium oxide nanoparticles (CeOz-NPs). The aim of the study was also to prepare $\mathrm{CeO}_{2}-\mathrm{NPS}$ and to investigate the particles sizes, texture and morphology. Antioxidant/reducing properties of Vitex cannabifolia leaves extract were studied using Folin-Chiocalteu and 2,2-diphenyl-1-picrylhydrazyl (DPPH) tests, composition of the extract was explored by means of laser desorption/ionization time-of-flight mass spectrometry method. The extract was found to possess very high antioxidant/reducing capability, showing fast reduction of DPPH radicals even at 100-fold dilution. The main components of the extract were phenolic acids, flavonoids and terpenes; all these compounds are known to be active reducing and/or stabilizing agents in green synthesis of various nanoparticles. Using the extract, $\mathrm{CeO}_{2}-\mathrm{NPS}$ were prepared by means of the procedure that included the reduction of cerium(IV) ammonium nitrate by extract components followed by annealing the precipitate at $600{ }^{\circ} \mathrm{C}$ under in air conditions. The particles synthesized were characterized by means of scanning electron microscopy, X-ray diffraction and nitrogen adsorption methods. According to X-ray diffraction and electron microscopy data, $\mathrm{CeO}_{2}-\mathrm{NPS}$ had crystalline structure, spherical form and fairly uniform particles size distribution; surface area of the particles was estimated from nitrogen adsorption isotherms as about $30 \mathrm{~m}^{2} \mathrm{per} 1 \mathrm{~g}$. The average crystallite size determined from X-ray line broadening data was about $17 \mathrm{~nm}$, the average particles diameter derived from surface area data was up to $\sim 30 \mathrm{~nm}$. Thus, one can conclude that the particles synthesized are small enough to be suitable for biomedical applications while Vitex cannabifolia extract is the effective reagent for green synthesis of cerium oxide nanoparticles.
\end{abstract}

Keywords: Vitex cannabifolia leaves extract, green synthesis, cerium oxide nanoparticles, antioxidant/reducing properties, LDI MS, SEM, X-ray diffraction

\section{INTRODUCTION}

The potential application of cerium oxide nanoparticles $\left(\mathrm{CeO}_{2}-\mathrm{NPs}\right)$ in biological and medical fields is very promising [1-3]. $\mathrm{CeO}_{2}-\mathrm{NPs}$ have shown protective effects on human health by reducing ischemic brain damage, inhibiting the progression of some blind diseases, diabetes, Alzheimer's disease, atherosclerosis. Also cerium nanoparticles exhibit antioxidant, antitumor, antibacterial and antiviral properties [3]. They are used as effective UV filters in sunscreen cosmetics, too [4].

Among the methods for synthesis of $\mathrm{CeO}_{2}-\mathrm{NPs}$ for biomedical applications, green synthesis using plant extracts is of especial interest $[1,5]$. Plant extracts can perform both the function of reducing and stabilizing agents that allows ones to use no toxic organic solvent and reagent and to carry out the reaction under mild synthesis conditions. Thus, synthesized nanoparticles do not contain toxic products and surfactants and can be more stable than the particles produced by traditional methods [1].
Recently, green synthesis of $\mathrm{CeO}_{2}$-NPs was reported using different plants, such as Aloe vera, Gloriosa superba, Acalypha indica [5-7]. However, the synthesized nanoparticles were generally so large in size that, according to literature, they were not appropriate for biomedical applications [2,8]. Our previous studies have shown that the Vitex genus plant possesses high antioxidant/reducing properties and has a great potential in synthesis of silver nanoparticles. The active ingredients of Vitex genus leaves extracts are phenols, terpenoids and monosaccharides; these compounds are well known as reducing agents and are capable to reduce metal salts and to convert them to nanoparticles.

The aim of the work was to study Vitex cannabifolia leaves extract as a possible active agent for $\mathrm{CeO}_{2}-\mathrm{NPs}$ preparation, to prepare $\mathrm{CeO}_{2}$-NPs using the extract and to characterize the extract and the particles synthesized.

\section{EXPERIMENTAL}

Vitex cannabifolia plants were used for green synthesis of $\mathrm{CeO}_{2}$-NPs. The biologically 
active substances were extracted from the leaves with $70 \%$ ethanol solution according to the procedure described in [9]. $100 \mathrm{ml}$ of $70 \%$ ethanol was added to $1 \mathrm{~g}$ of finely chopped leaves, after that the mixtures were placed into steam bath for $30 \mathrm{~min}$. After cooling, the extract was adjusted to the initial volume and filtered.

The total concentration of phenolic antioxidant/reducing agents in the extracts was evaluated by using the Folin-Ciocalteu method. To measure the total phenol index [10], $11.5 \mathrm{ml}$ of water, $5 \mathrm{ml}$ of $20 \%$ sodium carbonate solution, $1.25 \mathrm{ml}$ of Folin-Ciocalteu reagent (Merck) and $6.25 \mathrm{ml}$ of water were consecutively added to $1 \mathrm{ml}$ of extract. The solution was stirred for $30 \mathrm{~min}$, then the absorbance at $750 \mathrm{~nm}$ was measured, and the total phenol index was calculated in accordance with the protocol [10]. By comparison of the obtained values of phenol index of the extracts with the corresponding data for ascorbic acid (total phenol index for the $0.5 \mathrm{mM}$ solution of ascorbic acid was equal to 1 [11]), the equivalent concentration of the antioxidant in solutions was estimated.

To determine the total content of flavonoids, we used the method based on the capability of the compounds to form a coloured complex with aluminium chloride. $1 \mathrm{ml}$ of extract, prepared as described above, was placed in volumetric flask, $5 \mathrm{ml}$ of $2 \%$ solution of $\mathrm{AlCl}_{3}$ (Sigma-Aldrich) in $95 \%$ ethanol was added into the glass, and then $95 \%$ ethanol was added to reach a volume of $25 \mathrm{ml}$. The mixture was stirred for $30 \mathrm{~min}$ and the optical density of the solution at $410 \mathrm{~nm}$ was measured. To prepare a blank solution, $0.1 \mathrm{ml}$ of concentrated acetic acid was added to $1 \mathrm{ml}$ of extract, followed by the dilution of the mixture by $95 \%$ ethanol to the total volume of $25 \mathrm{ml}$. To prepare reference samples, the rutin (SigmaAldrich) solutions of different concentrations were prepared, using $95 \%$ ethanol as a solvent [12]. Total content of flavonoids was expressed as the equivalent weight of rutin per $1 \mathrm{~g}$ of dried leaves.

Antioxidant/reducing activity of Vitex extract was evaluated using 2,2-diphenyl-1picrylhydrazyl (DPPH) radical scavenging method [13]. $1 \mathrm{ml}$ of original was placed into glass and $2 \mathrm{ml}$ of $70 \%$ ethanol and $2 \mathrm{ml}$ of $0.15 \mathrm{mM}$ DPPH solution were consecutively added to the glass. The solution was shaken at $25{ }^{\circ} \mathrm{C}$ for 5-120 min. The change in concentration of stable radicals in reaction mixture during the reaction was determined from the change in absorption at the maximum of $520 \mathrm{~nm}$ as compared to absorption value for control solution. To prepare control solution, $3 \mathrm{ml}$ of $70 \%$ ethanol was mixed with $2 \mathrm{ml}$ of $0.15 \mathrm{mM}$ DPPH solution.

Qualitative analysis of extracts composition was performed by means of laser desorption/ionization time-of-flight mass spectrometry (LDI MS). Mass spectra were recorded in positive and negative-ion extraction mode on Autoflex II mass spectrometer (Bruker Daltonics Inc., Germany) equipped with a nitrogen laser $(337 \mathrm{~nm})$. The samples were ionized in the pulse mode: pulse length $3 \mathrm{~ns}$, frequency $20 \mathrm{~Hz}$; maximum energy $65 \mathrm{~mJ}$. Spectra were recorded in the reflection mode using a delayed extraction of $20 \mathrm{~ns}$ and accelerating voltage $20 \mathrm{kV}$. The resulting mass spectra were the sum of 100 individual spectra.

To produce $\mathrm{CeO}_{2}-\mathrm{NPs}, 100 \mathrm{ml}$ of $0.01 \mathrm{M}$ ammonium cerium(IV) nitrate solution was added to $10 \mathrm{ml}$ of plant extract. The reaction mixture was stirred for $3 \mathrm{~h}$ at $80^{\circ} \mathrm{C}$, cooled to room temperature and stored for 2 days. The precipitate was powdered and annealed at $600^{\circ} \mathrm{C}$ for $2 \mathrm{~h}$.

XRD patterns of the nanoparticles were obtained at a DRON-4-07 diffractometer (Firm "Burevestnik", Russia) with filtered $\mathrm{Cu} K_{\alpha}$ radiation in geometry of Bregg-Brentano in $2 \theta$ range of $10-80^{\circ}$. Phase identification was performed using the database of JCPDS. The average size of crystallites was calculated from $\mathrm{X}$-ray data according to Scherrer formula.

Scanning electron microscopic (SEM) images were recorded using a Gemini 500 electron microscope (Zeiss, Germany). The samples powder was grind on a standard holder that was pre-coated with a double-sided conductive graphite tape. The remaining powder was blown out from the tape in a stream of dry nitrogen. An aperture of $20 \mu \mathrm{m}$ was used with an acceleration voltage of $1-2 \mathrm{kV}$. Secondary electron detector was manly used, which allowed omitting fast surface charging.

$\mathrm{UV} / \mathrm{Vis}$ spectra of plant extracts and reaction mixtures were recorded on a Perkin Elmer Lambda $35 \mathrm{UV} / \mathrm{Vis}$ double beam Spectrophotometer at $25^{\circ} \mathrm{C}$ in the wavelength range of $200-800 \mathrm{~nm}$. Scanning speed was $480 \mathrm{~nm} / \mathrm{min}$, pathlength of cuvette (Perkin-Elmer) was $10 \mathrm{~mm}$.

Textural characteristics of $\mathrm{CeO}_{2}$-NPs were derived from $77 \mathrm{~K}$ nitrogen adsorption isotherms using several standard methods (BET, $t$-plot, 
DH, DR methods). Isotherms were recorded and processed on an AUTOSORB-6B (Quantachrome, USA).

\section{RESULTS AND DISCUSSIONS}

The data characterizing the antioxidant/reducing properties of Vitex cannabifolia leaves extract (the values of the total phenolic index and the equivalent concentration of ascorbic acid) as well as the data on the flavonoid content in the plant leaves are presented in Table 1. As one can see from the data, the extract contains high amount of phenols and flavonoids. The extract also possesses high antiradical/reducing properties, as it is shown in the reaction of strongly diluted extract with DPPH radicals (Fig. 1).

The more detailed study of the extract composition was carried out using LDI MS method. The appropriate data are given in Fig. 2 and in Table 2.

Table 1. Content of phenolic antioxidants in the Vitex cannabifolia leaves and extract

\begin{tabular}{cccc}
\hline Sample & $\begin{array}{c}\text { Total } \\
\text { Phenolic } \\
\text { index }\end{array}$ & $\begin{array}{c}\text { Equivalent concentration of } \\
\text { ascorbic acid in extract, } \\
\text { mmol/L }\end{array}$ & $\begin{array}{c}\text { Content of flavonoids per } \\
\mathbf{1} \text { g of dried leaves, \% }\end{array}$ \\
\hline Leaves of Vitex cannabifolia & 15.0 & 7.5 & 1.2 \\
\hline
\end{tabular}

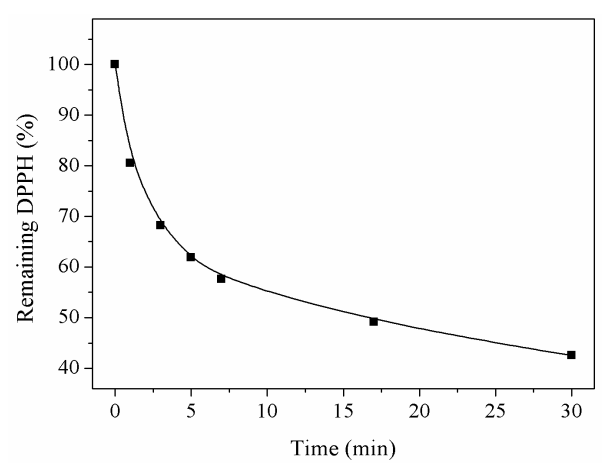

Fig. 1. Inhibition of DPPH radical in reaction with Vitex cannabifolia extract. Before measurement the extract was diluted by 100 times

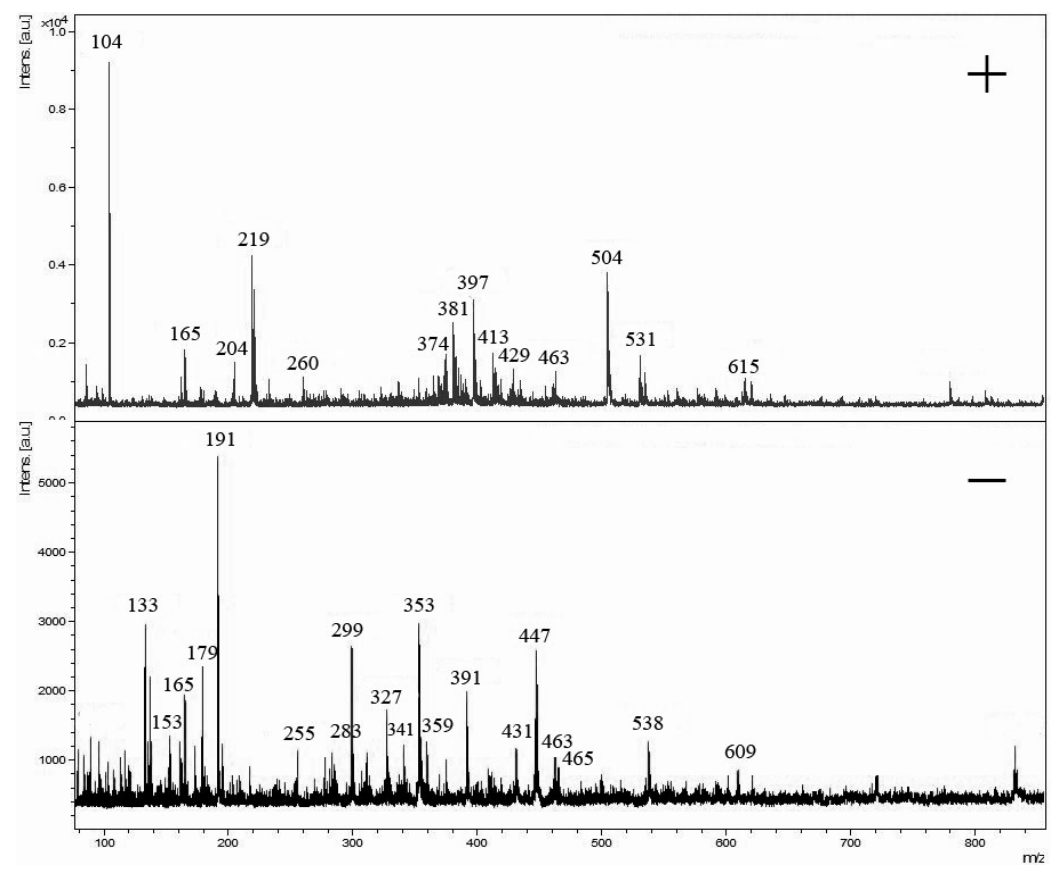

Fig. 2. Fragments of negative $(-)$ and positive $(+)$ ion mode of LDI mass spectra of Vitex cannabifolia extract 
Table 2. The most abundant ions in the negative and positive modes of mass spectra of Vitex extracts

\begin{tabular}{|c|c|c|c|}
\hline$m / z$ & Compound, ion & $m / z$ & Compound, ion \\
\hline $133^{-}$ & Cinnamyl alcohol, $[\mathrm{M}-\mathrm{H}]^{-}$ & $374^{+}$ & Casticin, $\mathrm{M}^{+}$ \\
\hline $137^{-}$ & Hydroxybenzoic acid, $[\mathrm{M}-\mathrm{H}]^{-}$ & $381^{+}$ & $\begin{array}{l}\text { Lactose / Cellobiose / Maltose / Sucrose, } \\
{[\mathrm{M}+\mathrm{K}]^{+}}\end{array}$ \\
\hline $153^{-}$ & $\begin{array}{l}\text { Terpinenol, }[\mathrm{M}-\mathrm{H}]^{-} / \\
\text {Dihydroxybenzoic acid, }[\mathrm{M}-\mathrm{H}]^{-}\end{array}$ & $397^{+}$ & $\begin{array}{l}\text { Casticin, } \quad[\mathrm{M}+\mathrm{Na}]^{+} \\
\text {Stigmasterol glucoside, }[\mathrm{M}+1-\text {-глюкоза }]^{+}\end{array}$ \\
\hline $165^{+}$ & $\begin{array}{l}\text { Eugenol, }[\mathrm{M}+\mathrm{H}]^{+} / \text {Hydroxycinnamic acid, } \\
{[\mathrm{M}+\mathrm{H}]^{+}}\end{array}$ & $413^{+}$ & Stigmasterol, $\mathrm{M}^{+}$ \\
\hline $179^{-}$ & $\begin{array}{l}\text { Glucose/Galactose/Fructose/Caffeic acid, } \\
{[\mathrm{M}-\mathrm{H}]^{-}}\end{array}$ & $416^{+}$ & Methylenedioxypentamethoxyflavone, $\mathrm{M}^{+}$ \\
\hline $191^{-}$ & Citric acid / Scopoletin, $[\mathrm{M}-\mathrm{H}]^{-}$ & $429^{+}$ & $\begin{array}{l}\text { Vitetrifolin } \mathrm{D},[\mathrm{M}+\mathrm{Na}]^{+} / \\
\text {Friedelind, }[\mathrm{M}+\mathrm{H}]^{+}\end{array}$ \\
\hline $219^{+}$ & Caryophyllene oxide, $[\mathrm{M}-\mathrm{H}]^{+}$ & $431^{-}$ & Vitexin / Isovitexin, $[\mathrm{M}-\mathrm{H}]^{-}$ \\
\hline $220^{+}$ & Spathulenol, $\mathrm{M}^{+}$ & $447^{-}$ & Orientin / Isoorientin / Cynaroside, $[\mathrm{M}-\mathrm{H}]^{-}$ \\
\hline $255^{-}$ & Hexadecanoic acid, $[\mathrm{M}-\mathrm{H}]^{-}$ & $463^{+}$ & Luteolin-glucuronide, $[\mathrm{M}+\mathrm{H}]^{+}$ \\
\hline $260^{+}$ & Cadinol, $[\mathrm{M}-\mathrm{H}+\mathrm{K}]^{+}$ & $463^{-}$ & Isoquercitrin, $[\mathrm{M}-\mathrm{H}]^{-}$ \\
\hline $283^{-}$ & $\begin{array}{l}\text { 6-methyl hexadecanoic acid methyl ester / } \\
\text { Stearic acid, }[\mathrm{M}-\mathrm{H}]^{-}\end{array}$ & $465^{-}$ & Agnuside, $[\mathrm{M}-\mathrm{H}]^{-}$ \\
\hline 299- & Trihydroxydimethoxyflavone, $[\mathrm{M}-\mathrm{H}]^{-}$ & $504^{+}$ & Cannabifolin $\mathrm{B},[\mathrm{M}+\mathrm{H}]^{+}$ \\
\hline $341^{-}$ & $\begin{array}{l}\text { Myzodendrone / Dicaffeic acid / Lactose / } \\
\text { Cellobiose / Maltose / Sucrose, }[\mathrm{M}-\mathrm{H}]^{-}\end{array}$ & $538^{-}$ & Caffeoylmussaenosidic acid, $[\mathrm{M}-\mathrm{H}]^{-}$ \\
\hline $353^{-}$ & Chlorogenic acid, $[\mathrm{M}-\mathrm{H}]^{-}$ & $609^{-}$ & $\begin{array}{l}\text { Caffeoylisoorientin / Hesperidine / Rutin, } \\
{[\mathrm{M}-\mathrm{H}]^{-}}\end{array}$ \\
\hline $359^{-}$ & Chrysosplenol / Centauredin, $[\mathrm{M}-\mathrm{H}]^{-}$ & & \\
\hline
\end{tabular}

Fig. 2 shows the most abundant ions in the negative and positive modes of mass spectra while Table 2 gives possible interpretation of all the signals identified. For signals attribution, the literature data [14-19] were used.

As one can conclude from the data, the most intensive signals in the mass spectra are due to compounds related to phenolic antioxidants. Indeed, 15 of the 25 most pronounced peaks can be referred to phenolic acids (dihydroxybenzoic acid, hydroxycinnamic acid, caffeic acid, chlorogenic acid) and flavonoids (trihydroxydimethoxyflavone, chrysosplenol/centauredin, casticin, methylenedioxypentamethoxyflavone, vitexin/isovitexin, orientin/isoorientin/cynaroside, luteolin-glucuronide, isoquercitrin, caffeoylisoorientin/hesperidine/rutin). Extract also seems to contain citric acid, mono- and disaccharides (glucose/galactose/fructose and lactose/cellobiose/maltose/sucrose), terpenes and terpenoids (terpinenol, cannabifolin B, caryophyllene oxide, spathulenol, cadinol, vitetrifolin D, agnuside, caffeoylmussaenosidic acid). All these compounds are known to be active reducing and/or stabilizing agents in green synthesis of various nanoparticles.

Fig. 3 shows the SEM image of $\mathrm{CeO}_{2}-\mathrm{NPs}$ particles synthesized using Vitex extract. The particles seem to have a rather spherical form and fairly uniform particle size distribution. Fig. 4 gives the X-ray diffraction curve; the data confirm crystalline structure of the particles. The average crystallite size determined from X-ray line broadening data is $\sim 17 \mathrm{~nm}$.

Table 3 gives the data on the texture of $\mathrm{CeO}_{2}$-NPs derived from nitrogen adsorption experiment. The results show that the sample is non-porous powder; the estimated total pore volume and volume of micropores are small enough to be referred to the slits and cavities between the particles.

Average particles sizes may be estimated also from the surface area data. As one can see from the data of Table 3, surface area of the $\mathrm{CeO}_{2}$-NPs powder is about $26-31 \mathrm{~m}^{2} / \mathrm{g}$. Taking into account the bulk density of $\mathrm{CeO}_{2}$ $\left(7.215 \mathrm{~g} / \mathrm{cm}^{3}\right)$, one can estimate the average diameter of the particles as $D=(26 \div 30) \mathrm{nm}$. This value is approximately 1.7 times higher 
than the average diameter of crystallites $(17 \mathrm{~nm})$, that is the volume of the particle is approximately 5 times higher than the average volume of the crystallite. Perhaps, each particle consists of 5 or more smaller crystallites, with the slits between the crystallites and the particles of various sizes being the micropores and larger pores.

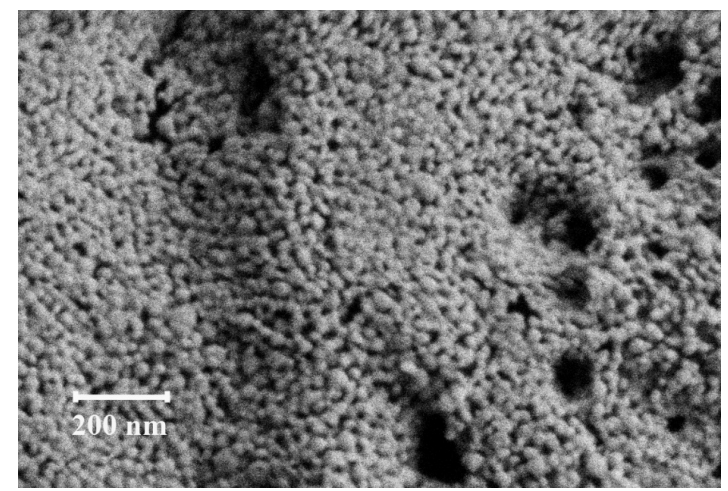

Fig. 3. SEM image of $\mathrm{CeO}_{2}$-NPs

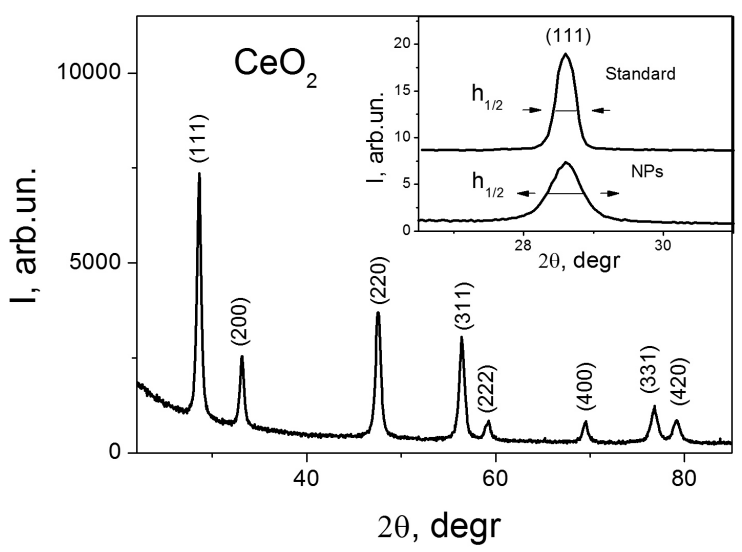

Fig. 4. XRD pattern of $\mathrm{CeO}_{2}-\mathrm{NPs}$

Table 3. Surface area and pore volume for $\mathrm{CeO}_{2}-\mathrm{NPs}$

\begin{tabular}{|c|c|c|c|c|c|c|}
\hline \multirow[t]{2}{*}{ Sample } & \multirow{2}{*}{$\begin{array}{c}\text { BET } \\
S_{\text {BET, }} \mathbf{m}^{2} / \mathbf{g}\end{array}$} & \multirow{2}{*}{$\begin{array}{l}t \text {-method } \\
S_{\text {ext }}, \mathbf{m}^{2} / \mathrm{g}\end{array}$} & \multicolumn{2}{|c|}{$\begin{array}{c}\text { DH method } \\
\text { (adsorption/desorption) }\end{array}$} & \multicolumn{2}{|c|}{ DR method } \\
\hline & & & $\begin{array}{l}\text { (adsorptio } \\
S_{\text {total }}, \mathbf{m}^{2} / \mathrm{g}\end{array}$ & $\begin{array}{l}\text { Hesorption) } \\
V_{\text {total }} \mathbf{c m}^{3} / \mathbf{g}\end{array}$ & $S_{\mathrm{mi}}, \mathbf{m}^{2} / \mathrm{g}$ & $V_{\mathrm{mi}}, \mathbf{c m}^{3} / \mathrm{g}$ \\
\hline $\mathrm{CeO}_{2}-\mathrm{NPs}$ & 30 & 30 & $26 / 31$ & $0.012 / 0.012$ & 13 & 0.005 \\
\hline
\end{tabular}

$S_{\mathrm{BET}}-$ surface area by BET method, $S_{\mathrm{ext}}-$ external surface area by $t$ - method,

$S_{\text {total }}$ and $V_{\text {total }}$ - cumulative surface area and pore volume by DH method,

$S_{\mathrm{mi}}$ and $V_{\mathrm{mi}}$ - micropore surface area and micropore volume by DR method

\section{CONCLUSIONS}

The results obtained show that leaves extract of Vitex cannabifolia is very effective antioxidant/reducing agent, which can be used for green synthesis of crystalline $\mathrm{CeO}_{2}$ nanoparticles. The extract contains high amount of phenols and terpenoids; these compounds can act both as reducing agents and as stabilizing agents preventing particles growth during synthesis. Produced $\mathrm{CeO}_{2}$ nanoparticles were shown to have crystalline structure, spherical form and fairly uniform particles size distribution. The sizes of the particles do not exceed $\sim 30 \mathrm{~nm}$ that make them suitable for biomedical applications. 


\title{
Синтез наночастинок оксиду церію з використанням Vitex екстракту
}

\author{
Т.В. Фесенко, І.В. Лагута, О.М. Ставинська, О.І. Оранська
}

Інститут хімії поверхні ім. О.О. Чуйка Національної академії наук Украӥни вул. Генерала Наумова, 17, Київ, 03164, Україна, t.fesenko@gmail.com

\begin{abstract}
Метою дослідження було вивчення складу та антиоксидантних/відновлювальних властивостей екстракту 3 листя Vitex cannabifolia i характеризація екстракту як можливого активного агента для зеленого синтезу

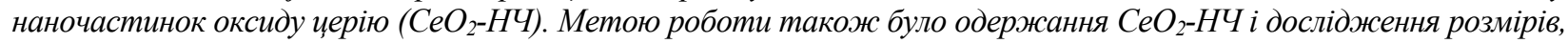
текстури та морфології синтезованих наночастинок. Антиоксидантні/відновлювальні властивості екстракту 3 листя Vitex cannabifolia було досліджено за допомогою методу Фоліна-Чокальтеу та 2,2-дифеніл-1пікрилгідразилу (ДФПГ)-тесту, склад екстракту вивчено $з$ використанням методу лазерної десорбиійної/іонізачійної часопрольотної мас-спектрометрії. Знайдено, щуо екстракт має дуже високі актиоксидантні/відновлювальні властивості, демонструючи швидке відновлення радикалів ДФПГ навіть при 100-кратному розведенні. Основними компонентами екстракту були фенольні кислоти, флавоноїди та терпени; як добре відомо, иі сполуки є активними відновлювальними та/або стабілізуючими агентами в зеленому синтезі різних наночастинок. 3 використанням екстракту було одержано СеО2 відновлення амонію иерію(IV) нітрату компонентами екстракту та наступного відпалу осаду при $600{ }^{\circ} \mathrm{C}$ на повітрі. Синтезовані частинки було охарактеризовано методами скануючої електронної мікроскопії, иирококутового рентгенівського розсіювання та адсорбиії азоту. Згідно даних електронної мікроскопї та рентгенофазового аналізу, СеО2-HЧ мали кристалічну структуру, сферичну форму $і$ достатньо однорідний розподіл за розмірами; за даними експерименту по адсорбиї азоту, питома поверхня наночастинок складала близько $30 \mathrm{M}^{2}$ на 1 г. Середній розмір кристалітів, визначений з даних щзоо уширення рентгенівських ліній, становив 17 нм, середній діаметр частинок, визначений з даних щуодо площі їхньої поверхні, не перевищував >30 нм. Таким чином, можна зробити висновок, що синтезовані частинки мають достатньо маленькі розміри $і \epsilon$ придатними для використання в біологї та медицині, а екстракт Vitex cannabifolia є ефективним реагентом для зеленого синтезу наночастинок оксиду иерію.
\end{abstract}

Ключові слова: екстракт із листя Vitex cannabifolia, зелений синтез, наночастинки оксиду иерію, антиоксидантні / відновлювальні властивості, ЛДІ МС, СЕМ, рентгенофазовий аналіз

\section{Синтез наночастиц оксида церия с использованием Vitex экстракта}

\author{
Т.В. Фесенко, И.В. Лагута, О.Н. Ставинская, О.И. Оранская
}

Институт химии поверхности им. А.А. Чуйко Национальной академии наук Украинь ул. Генерала Наумова, 17, Киев, 03164, Украина, t.fesenko@gmail.com

Целью исследования было изучение состава и антиоксидантных/восстановительных свойств экстракта из листьев Vitex cannabifolia и характеризация экстракта как возможного активного агента для зеленого синтеза наночастиц оксида церия (СеО2-НЧ). Целью работи также было получение СеО $\mathrm{C}_{2}-\mathrm{HЧ}_{2}$ и изучение размеров, текстурь и морфологии синтезированных наночастии. Антиоксидантные/восстановительные свойства экстракта из листьев Vitex cannabifolia были изучены с помощью метода Фолина-Чокальтеу и 2,2-дифенил-1пикрилгидразила (ДФПГ)-теста, состав экстракта исследован с помощью метода лазерной десорбционной/ионизачиинной времяпролетной масс-спектрометрии. Обнаружено, что экстракт обладает очень высокой антиоксидантной / восстанавливающей способностью, демонстрируя быстрое восстановление радикалов ДФПГ даже при 100-кратном разведении. Основными компонентами экстракта были фенольные кислоты, флавоноиды и терпены, которые, как известно, являются активными восстанавливающими и/или стабилизирующими агентами в зеленом синтезе различных наночастиц. С использованием экстракта были приготовлень СеО2-HЧ; процедура синтеза состояла из восстановления нитрата аммония иерия (IV) компонентами экстракта и последующего отжнга осадка при $600{ }^{\circ} \mathrm{C}$ на воздухе. Синтезированные частищь были охарактеризованы методами сканирующей электронной микроскопии, иирокоуглового рентгеновского

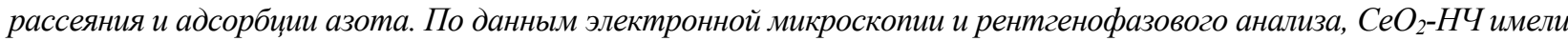


кристаллическую структуру, сферическую форму и достаточно однородное распределение частии по размерам; по данным эксперимента по адсорбции азота, удельная поверхность частии составляла около $30 \mathrm{M}^{2}$ на 1 г. Средний размер кристаллитов, определенный из данных по уширению рентгеновских линий, составил 17 нм, средний диаметр частии, определенный из данных о площади поверхности, не превышиал 30 нм. Таким образом, можно заключить, что синтезированные частицы достаточно маль, чтобы быть пригодными для применения в биологии и медицине, а экстракт является эффективным реагентом для зеленого синтеза наночастиц оксида церия.

Ключевые слова: экстракт из листьев Vitex cannabifolia, зеленый синтез, наночастицы оксида цеерия, антиоксидантные / восстанавливающие свойства, ЛДИ МС, СЭМ, рентгенофазовый анализ

\section{REFERENCES}

1. Singh K.R.B., Nayak V., Sarkar T., Singh R.P. Cerium oxide nanoparticles: properties, biosynthesis and biomedical application. RSC $A d v$. 2020. 10(45): 27194.

2. Gagnon J., Fromm K.M. Toxicity and protective effects of cerium oxide nanoparticles (nanoceria) depending on their preparation method, particle size, cell type, and exposure route. Eur. J. Inorg. Chem. 2015. 2015(27): 4510.

3. Rajeshkumar S., Naik P. Synthesis and biomedical applications of cerium oxide nanoparticles-a review. Biotechnol. Rep. 2018. 17: 1.

4. Boutard T., Rousseau B., Couteau C., Tomasoni C., Simonnard C., Jacquot C., Coiffard L.J.M., Konstantinov K., Devers T., Roussakis C. Comparison of photoprotection efficiency and antiproliferative activity of $\mathrm{ZnO}$ commercial sunscreens and $\mathrm{CeO}_{2}$. Mater Lett. 2013. 108: 13.

5. Charbgoo F., Ahmad M.B., Darroudi M. Cerium oxide nanoparticles: green synthesis and biological applications. Int. J. Nanomedicine. 2017. 12: 1401.

6. Arumugam A., Karthikeyan C., Haja Hameed A.S., Gopinath K., Gowri S., Karthika V. Synthesis of cerium oxide nanoparticles using Gloriosa superba L. leaf extract and their structural, optical and antibacterial properties. Mater. Sci. Eng. C. 2015. 49: 408.

7. Kannan S.K., Sundrarajan M. A green approach for the synthesis of a cerium oxide nanoparticle: characterization and antibacterial activity. Int. J. Nanosci. 2014. 13(3): 1450018.

8. Kumar A., Das S., Munusamy P., Self W., Baer D.R., Sayle D.C., Seal S. Behavior of nanoceria in biologicallyrelevant environments. Environ. Sci. Nano. 2014. 1(6): 516.

9. Komarova M.N., Nikolaeva L.A., Regir V.G. Phytochemical analysis of medicinal plants: guidelines for laboratory studies. (Saint-Petersburg: State Chem.-Pharmaceut. Acad., 1998). [in Russian].

10. Alonso A.M., Domianguez C., Guillean D., Barroso C.G. Determination of antioxidant power of red and white wines by a new electrochemical method and its correlation with polyphenolic content. J. Agric. Food Chem. 2002. 50(11): 3112 .

11. Stavinskaya O.M., Kuzema P.O., Laguta I.V., Pakhlov E.M., Kazakova O.O. Chernyavskaya T.V. Interaction of ascorbic acid with hydrophilic-hydrophobic silicas. Ann. Univ. Mariae Curie-Sklodowska. Chemia. 2007. 62: 124.

12. State enterprise "Scientific and Expert Pharmacopoeial Center". State Pharmacopoeia of Ukraine. 1st ed., suppl. 1. (Kharkiv: RIREG, 2004). [in Ukrainian].

13. Brand-Williams W., Cuvelier M.E., Berset C. Use of a free radical method to evaluate antioxidant activity. $L W T$ - Food Sci. Technol. 1995. 28(1): 25.

14. Rani A., Sharma A. The genus Vitex: a review. Pharmacogn. Rev. 2013. 7(14): 188.

15. Hirobe C., Qiao Z.S., Takeya K., Itokawa H. Cytotoxic flavonoids from Vitex agnus-castus. Phytochemistry. 1997. 46(3): 521.

16. Li W.X., Cui C.B., Cai B., Wang H.Y., Yao X.S. Flavonoids from Vitex trifolia L. inhibit cell cycle progression at G2/M phase and induce apoptosis in mammalian cancer cells. J. Asian Nat. Prod. Res. 2005. 7(4): 615.

17. Ahmad B., Azam S., Bashir S., Adhikari A., Choudhary M.I. Biological activities of a new compound isolated from the aerial parts of Vitex agnus castus L. Afr. J. Biotechnol. 2010. 9(53): 9063.

18. Kuruüzüm-Uz A., Güvenalp Z., Ströch K., Demirezer Ö., Zeeck A. Antioxidant potency of flavonoids from Vitex agnus-castus L. growing in Turkey. Fabad J. Pharm. Sci. 2008. 33(1): 11.

19. Tsurkan O., Nizhenkovska I., Yushchishena O., Kovalska N., Korablova O. Determination of iridoids in Vitex agnus-castus L. and Vitex cannabifolia Sieb. Farmatsevtychnyi Zhurnal. 2019. 2: 101. 